\title{
BOARD OF DIRECTORS \& TOP MANAGEMENT TEAM GENDER DIVERSITY IN EUROPEAN COMPANIES
}

\author{
Tomáš MICHALIČKA, Drahoslav LANČARIČ, Xénia SZARKOVÁ
}

Slovak University of Agriculture in Nitra, Faculty of Economics and Management, Department of Management

\begin{abstract}
Purpose: In recent years, corporate social responsibility (CSR) has become a strategic issue for many companies, which do not hesitate to invest a lot of their resources into this concept in order to do their businesses alongside with the positive influence on the society they are part of. One of the areas where the legacy of CSR is continuously increasing is also human resources management (HRM). As a result, diversity, and inclusion together with gender and racial equal career opportunities are areas, which are now very often part of official goals especially of international corporations. The focus of our paper is on gender diversity and equal career opportunities as part of CSR activities in HRM. Using data about 247 large European companies we analyse board of directors and top management team gender diversity. In more details, we review gender diversity of positions within top management and identify leadership roles with highest share of women representatives. We also evaluate leadership gender diversity from different aspects like country, industry, ownership structure, year of the establishment and other. Based on the results we propose a hypothetical profile of ideal company, in which the career growth of women and their chances to become member of board of directors or top management team should not be limited by any type of gender discrimination or prejudice.

Design/methodology/approach: Data used in this research were retrieved from TP Catalyst Database. To analyse raw downloaded data, data-mining methods like classification, clustering and summarization were used. To identify leadership gender diversity structure, percentage of male and female representatives within board of directors and top management team was calculated. Results were then sorted, ranked, and compared using selected criteria like country, business activity, ownership structure, year of the establishment and other.

Findings: This study provides valuable information for company and government decision makers about board and top management gender diversity and equal career opportunities from the perspective of CSR activities in HRM within large European companies. Identified are countries, industries, and other company characteristics with the highest share of women representatives within company leadership roles.

Research limitations: This study does not analyse the impact of external factors like legislation, incentives, regulation, etc. on company leadership gender diversity and on CSR activities in HRM, which could be the focus of the future research.

Practical implications: The paper supports the notion that gender diversity is an important corporate governance issue. If firms wish to provide correct signals regarding board independence and effectiveness, they should also consider some of the qualitative aspects such as gender diversity. The gender diversity might even act as a substitute for board independence.

Social implications: Acknowledging the role of women in corporate governance best practices can potentially increase the effectiveness of independent directors as it decreases the negative signal of an unbalanced gender board. Female directors send a positive signal to the public regarding a firm's ethical behaviour towards the society they are part of.
\end{abstract}

Keywords: gender, diversity, company, management, leadership

https://doi.org/10.11118/978-80-7509-820-7-0219 


\section{Introduction}

In the current socio-economic environment, increasing number of companies realize the importance of corporate social responsibility (CSR). One of the areas where the legacy of CSR is continuously increasing is also human resources management (HRM). It is a topic especially for big multicultural corporations, that have recognized their employees as one of the most important assets the company can have and therefore, they have set up diversity and inclusion, together with gender and racial equal career opportunities as part of their official goals.

The focus of this study is on gender diversity and equal career opportunities as a part of CSR activities in HRM. We analyse board and top management team gender diversity and identify leadership roles within top management with highest share of women representatives. We also evaluate leadership gender diversity from different company characteristics perspective. Based on the results we propose a hypothetical profile of ideal company, in which the career growth of women and their chances to become a member of leadership team should not be limited by any type of gender discrimination or prejudice.

This study provides valuable information for company and government decision makers about board and top management gender diversity and equal career opportunities from the perspective of CSR activities in HRM. According to various studies, gender leadership diversity seems to be an important factor in improving of the social and environmental performance of companies. The presence of women indicates that boards are more likely to make strategic decisions aimed at improving information transparency regarding CSR. Female directors send a positive signal to the public regarding a firm's ethical behaviour towards the society they are part of. However, the results of our study indicate the existence of persistent dominance of male leaders within large European companies.

\section{Literature review / Research background}

The issue of gender diversity on the labour market on different levels has earned a significant attention during the last years. Even though it is a frequently debated topic, there are several research articles that prove the poor representation of women at leadership positions (e.g., Patel et al. 2020, p. 1; Ghaleb et al. 2021, p. 6; Capers et al. 2021, p. 3). Potvin et al. (2018, p. 5) confirmed that in cultures with smaller board sizes and more females in leadership positions, the board representation of women is higher. In fact, the share of women leaders and their effect on the company's performance depends on the country, industry, or socio-economic factors (Hedija, Němec 2021, p. 159).

Diversity and the presence of women has various benefits on the leadership team, such as better problem-solving tools, more effective solutions, and broader thinking (Reddy, Adhikari, Chitranski 2017, p. 40). Furthermore, companies that support diversity, e.g., employ more women directors tend to create far-seeing and integral CSR board strategy, that has the potential to develop superior environmental and social performance of the company (Shaukat, Qiu, Trojanowski 2016, p. 569). Also, 
Nielsen and Huse (2010, p. 13) demonstrated in their theories that women on boards are more likely to support others, accept new ideas, help to solve relational and interpersonal issues.

In general, typical leadership traits are more preferably associated with men than women, which besides other negative stereotypes associated with women, could keep women from the election for leadership positions (Sczesny et al. 2004, p. 632). On the other hand, men are considered as independent, dominant, result- and taskoriented, that explains why men work more often at leader positions as women (Tannen 1991, p. 158).

Since the importance of CSR is more and more recognized by various societies, businesses' efforts of CSR activities are noticeable also by employees who are looking for a new job, that also leads to consumer behaviour change and in the case of companies that ignore CSR provokes poor reputation (Feng, Groh, Wang 2020, p.1). Multinational corporations have recognized that their employees are one of the most important stakeholders in social responsibility. Encouragement of personnel advancement in the company's hierarchy, as well as promotion of women in leadership positions, are two key priorities for these businesses. Simultaneously, the companies in a survey expressed a positive interest in diversification (Obrad, Gherhes 2018, p. 13).

\section{Methodology}

Based on the scope of our research, defined diversity dimensions and company characteristics, we set criteria for downloading the data from TP Catalyst database about companies that are analysed in this study. Because of the large volume of data, that each downloaded company profile from the database contained, we performed screening, pre-processing, and clustering of raw downloaded data, so they could be effectively used in the following stages of the research. Using already pre-processed downloaded data, we quantified board and top management gender diversity structure of companies (including top management positions) and classified companies within defined company characteristics. For classification of companies within company characteristics we either used categorization directly from the database or using information about companies from the database we performed our own categorization. As the next step, we did a ranking of companies based on the average board and top management female representatives $\%$ within each defined company characteristics. Based on the results of the ranking within each company characteristics criteria, we proposed hypothetical profile of ideal company and specific top management position where female career grow should not be limited by gender prejudice or stereotypes. As the last step we did summarization of results, draw conclusions, and identified limitations of the research.

Data for this research were downloaded from TP Catalyst database during December 2020. TP Catalyst is an online database used mainly for arm's-length benchmarking analysis. It contains extensive corporate ownership data including global coverage of companies around the globe, with detailed financials (Bureau van Dijk 2020). For the purpose of this research, we were able to process data about 
247 companies from 19 European countries. Countries in the scope were selected randomly to represent each geographical part of Europe. We focused only on very large companies (with over 100 employees), because companies of this size, in most of the countries, usually have regulatory obligation to publish information about their leadership representatives, which is the key input for this research. We also did not limit the selection of companies to any industry type or economy sector to get as comprehensive overview of results as possible, given the sample size. Based on the list of company leadership representatives, we identified for each company total number of board and top management male and female representatives. Consequently, we were able to quantify percentage of male and female representatives within Board of Directors and Top Management team. Using this approach, we also identified gender diversity structure of each Top Management position. In our study we analysed board and top management diversity structure from the point of view of eight selected company characteristics (Europe Geo. Region, Years on the Market, Public/Private, Family Business, Ownership Capital Origin, Ownership Capital Origin Country Economy, Business Activity, Economy Sector). Downloaded data from TP Catalyst database were used to classify all companies in our scope into specific categories within above mentioned company characteristics.

Using information about company country of residence, we classified companies into Europe Geo. Region categories (Annex A). Company date of incorporation was used for categorization of companies within Years on the Market criteria. For classification of companies within Public/Private and Business Activity characteristics was leveraged categorization available directly in the database. Information from database about company owner was used to categorize companies within Family Business characteristic. By comparing the residence country of the company owner and the residence country of the company, companies were classified into Ownership Capital Origin categories. Leveraging World Bank country classification by GNI per capita (World Bank 2021) and country of the company owner information from the database, companies were categorized within Ownership Capital Origin Country Economy characteristic (Annex B). Using NACE Rev. 2 main section company information from database, companies were categorized into Economy Sector characteristic (Annex C).

\section{Results and discussion}

Research was performed on the sample of 247 large companies from Europe. Most of the companies (51.4\%) were from Western Europe while least companies were from Central and Sothern regions with less than $10 \%$ representation. In the sample were more private (51.4\%) than public companies (47.4\%). From years on the market perspective, most companies $(43.3 \%)$ were on the market from 6 to 10 years while considering the limitation that figures within this company characteristic were not reflecting full history of the company, if the company went through restructuring, old company was liquidated and new one was set up. Only $17.4 \%$ of companies could be classified as family business comparing to $81 \%$, which 
were not. More than $50 \%$ of all companies were from tertiary sector while the smaller half was all together from primary, secondary and quaternary sector. Most of the companies (47.4\%) were doing business in Services and least (16.2\%) in Wholesale \& Retail. Domestic ownership capital had $75.3 \%$ of the companies comparing to only $21.9 \%$ companies with the foreign ownership capital. In case of $81.4 \%$ of the companies the ownership capital came from high-income economies followed by the ownership capital from middle-income economies (15.4\%) and only one company (representing 0.4\%) had ownership capital from low-income economy (Table 1).

Table 1. Characteristics of the research sample

\begin{tabular}{|l|c|l|c|l|c|}
\hline $\begin{array}{l}\text { Europe Geo. } \\
\text { Region }\end{array}$ & $\%$ & Public / Private & $\%$ & $\begin{array}{l}\text { Ownership capital origin } \\
\text { country economy }\end{array}$ & $\%$ \\
\hline Central & 9.7 & Private & 51.4 & High-income economies & 81.4 \\
\hline Eastern & 15.4 & Publicly quoted & 47.4 & Middle-income economies & 15.4 \\
\hline Nordics & 14.6 & $\begin{array}{l}\text { Formerly publicly } \\
\text { quoted }\end{array}$ & $1.2^{*}$ & Low-income economies & $0.4^{*}$ \\
\hline Southern & 8.9 & Family Business & $\%$ & n.a. & $2.8^{*}$ \\
\hline Western & 51.4 & No & 81.0 & Business Activity & $\%$ \\
\hline $\begin{array}{l}\text { Years on the } \\
\text { market }\end{array}$ & $\%$ & Yes & 17.4 & Services & 47.4 \\
\hline $1-5$ & 19.0 & n.a. & $1.6^{*}$ & Manufacturing & 36.4 \\
\hline $6-10$ & 43.3 & Economy Sector & $\%$ & Wholesale \& Retail & 16.2 \\
\hline $11-20$ & 17.0 & Primary & 3.6 & Ownership Capital Origin & $\%$ \\
\hline $20+$ & 20.6 & Secondary & 32.8 & Domestic & 75.3 \\
\hline \multirow{2}{*nnnyyy}{} & & Tertiary & 50.2 & Foreign & 21.9 \\
\cline { 2 - 6 } & Quaternary & 13.4 & n.a. & $2.8^{*}$ \\
\cline { 3 - 6 }
\end{tabular}

* Excluded values due to not available data or insufficient sample size.

Source: own research

Using calculated average board and top management female percentage, we ranked companies within each selected company characteristics (Europe Geo. Region, Years on the Market, Public/Private, Family Business, Ownership Capital Origin, Ownership Capital Origin Country Economy, Business Activity, Economy Sector). Higher average Board or Top Management female \%, equals to higher ranking of the company within specific criteria. Results of companies' leadership gender diversity ranking from the perspective of each analysed company characteristics are shown in Table 2. Top Management position with the highest female representatives is Administration department with $52 \%$ of female representatives, followed by Human Resources with $50 \%$ of female representatives. Least women within Top Management are working on the Operations \& Production $\&$ Manufacturing department (only 6\%). 
Table 2. Ranking of companies based on Board and Top Management avg. female $\%$

\begin{tabular}{|c|c|c|c|c|c|}
\hline \multirow[b]{2}{*}{ Company Characteristics } & \multirow[b]{2}{*}{ Category } & \multicolumn{2}{|c|}{ Board } & \multicolumn{2}{|c|}{ Top Management } \\
\hline & & $\begin{array}{c}\text { Avg } \\
\text { Female \% }\end{array}$ & Ranking & $\begin{array}{c}\text { Avg } \\
\text { Female \% }\end{array}$ & Ranking \\
\hline \multirow{5}{*}{ Europe Geo. Region } & Eastern & $24 *$ & 1 & $22 *$ & 1 \\
\hline & \begin{tabular}{|l|} 
Southern \\
\end{tabular} & $24 *$ & 2 & $17 *$ & 4 \\
\hline & \begin{tabular}{|l} 
Nordics \\
\end{tabular} & 23 & 3 & $22^{*}$ & 2 \\
\hline & Central & 16 & 4 & 15 & 5 \\
\hline & Western & 14 & 5 & $17 *$ & 3 \\
\hline \multirow{4}{*}{ Years on the Market } & $11-20$ & 22 & 1 & $20 *$ & 3 \\
\hline & $1-5$ & 21 & 2 & $20 *$ & 2 \\
\hline & $20+$ & 19 & 3 & 22 & 1 \\
\hline & $6-10$ & 14 & 4 & 15 & 4 \\
\hline \multirow{2}{*}{ Public / Private } & Publicly quoted & 23 & 1 & 21 & 1 \\
\hline & Private & 13 & 2 & 16 & 2 \\
\hline \multirow{2}{*}{ Family Business } & No & 18 & 1 & $18^{*}$ & 1 \\
\hline & Yes & 16 & 2 & $18^{*}$ & 2 \\
\hline \multirow{2}{*}{$\begin{array}{l}\text { Ownership Capital } \\
\text { Origin }\end{array}$} & Domestic & 20 & 1 & 20 & 1 \\
\hline & Foreign & 11 & 2 & 15 & 2 \\
\hline \multirow{2}{*}{$\begin{array}{l}\text { Ownership capital origin } \\
\text { country economy }\end{array}$} & High-income & $18^{*}$ & 1 & 18 & 2 \\
\hline & Middle-income & $18^{*}$ & 2 & 23 & 1 \\
\hline \multirow{3}{*}{ Business Activity } & \begin{tabular}{|l} 
Wholesale \& \\
Retail \\
\end{tabular} & 20 & 1 & $20 *$ & 2 \\
\hline & Manufacturing & 18 & 2 & 15 & 3 \\
\hline & Services & 17 & 3 & $20^{*}$ & 1 \\
\hline \multirow{4}{*}{ Economy Sector } & Tertiary & $19^{*}$ & 1 & 21 & 1 \\
\hline & Secondary & $19 *$ & 2 & 16 & 2 \\
\hline & Primary & 15 & 3 & 14 & 4 \\
\hline & Quaternary & 11 & 4 & 15 & 3 \\
\hline
\end{tabular}

* In case more categories had equal avg. board or top management female \%, higher ranking was assigned to category with the larger sample size.

Source: own research

Based on the results of the above-mentioned ranking, we proposed hypothetical profile of ideal company (Table 3) and specific top management position where female career grow should not be limited by gender prejudice or stereotypes. Using Board average female \%, the ideal company could be described as publicly quoted company from Eastern Europe with domestic ownership capital from high-income country economy. This company is on the market up to two decades. It is not familyowned company, doing business in wholesale \& retail and belonging to tertiary sector of economy. From Top Management perspective, the ideal company is as well not family owned publicly quoted company from Eastern Europe. It has domestic ownership capital from middle income economy. This company is doing business in services for more than two decades and belongs to tertiary sector of economy. 
As ideal top management position for women we propose and recommend Human Resources department (50\% of female representatives) over Administration (52\%) due to larger sample size (33 female representatives were identified within 43 companies in case of HR department vs. only 7 female representatives within 12 companies in case of Administration department).

Table 3. Ideal company hypothetical profile proposal based on avg. board and avg. top management female \%

\begin{tabular}{|l|c|c|c|c|}
\hline \multirow{2}{*}{ Company Characteristic } & \multicolumn{2}{|c|}{ Board } & \multicolumn{2}{c|}{ Top Management } \\
\cline { 2 - 5 } & $\begin{array}{c}\text { Top Ranking } \\
\text { Category }\end{array}$ & $\begin{array}{c}\text { Avg } \\
\text { Female \% }\end{array}$ & $\begin{array}{c}\text { Top Ranking } \\
\text { Category }\end{array}$ & $\begin{array}{c}\text { Avg } \\
\text { Female \% }\end{array}$ \\
\hline Europe Geo. Region & Eastern & 24.1 & Eastern & 21.7 \\
\hline Years on the market & $11-20$ & 22.5 & $20+$ & 21.6 \\
\hline Public / Private & Publicly quoted & 23.0 & Publicly quoted & 20.9 \\
\hline Family Business & No & 18.2 & No & 18.3 \\
\hline Ownership Capital Origin & Domestic & 19.9 & Domestic & 19.5 \\
\hline $\begin{array}{l}\text { Ownership Capital Origin } \\
\text { Country Economy }\end{array}$ & $\begin{array}{c}\text { High-income } \\
\text { economies }\end{array}$ & 18.0 & $\begin{array}{c}\text { Middle-income } \\
\text { economies }\end{array}$ & 22.7 \\
\hline Business Activity & Wholesale \& Retail & 20.1 & Services & 19.6 \\
\hline Economy Sector & Tertiary & 18.8 & Tertiary & 20.9 \\
\hline
\end{tabular}

Source: own research

Results of our research are signalling persistent dominance of male leaders within large European companies. Total average Board and Top Management female representation is only $18 \%$ while $44 \%$ of analysed companies does not have any female representative in the Board and 38\% of companies from our sample have no female representative in Top Management. Only $10 \%$ of analysed companies have equal or more female Board or Top Management members than male members. Similar results as our research have several other studies that also indicate low female representatives on leadership positions (e.g., Patel et al. 2020, p. 1; Ghaleb et al. 2021, p. 6; Capers et al. 2021, p. 3). Study performed by Potvin et al. (2018, p. 5) was more specific regarding its results as it confirms that board female representation is higher in companies with smaller Board sizes.

\section{Conclusion}

This study provides valuable information for company and government decision makers about board and top management gender diversity and equal career opportunities from the perspective of CSR activities in HRM within large European companies. Various studies suggest that gender diversity enhances the corporate governance mechanisms. It also appears to be an important factor in improving of the social and environmental performance of companies. The presence of women indicates that boards of directors are more likely to make strategic decisions aimed at improving information transparency regarding CSR. Furthermore, acknowledging the role of women in corporate governance best practices can potentially increase the effectiveness of independent directors as it decreases the negative signal of an 
unbalanced gender board. Female directors send a positive signal to the public regarding a firm's ethical behaviour towards the society they are part of.

However, the results of our study hint on the existence of persistent dominance of male leaders within large European companies. The average Board and Top Management female representation in the research sample is below $20 \%$ and more than $50 \%$ of analysed companies have no female representative in the Board. Only $10 \%$ of analysed companies have an equal or higher representation of female leaders when comparing to male.

There are also several limitations to this study. The paper does not analyse the impact of external factors like legislation, incentives, regulation, etc. on company leadership gender diversity and on CSR activities in HRM, which could also be the focus of the future research, as do the potential reasons behind current status.

\section{References}

1. Capers, Q.,IV, Johnson, A., Berlacher, K., Douglas, P. S. (2021), The Urgent and Ongoing Need for Diversity, Inclusion, and Equity in the Cardiology Workforce in the United States, „Journal of the American Heart Association“, https://doi.org/10.1161/JAHA.120.018893

2. Feng, X., Groh, A., Wang, Y. (2020), Board diversity and CSR, „Global Finance Journal“, 100578. https://doi.org/10.1016/j.gfj.2020.100578

3. Ghaleb, B. A. A., Qaderi, S. A., Almashaqbeh, A., Qasem, A. (2021), Corporate social responsibility, board gender diversity and real earnings management: The case of Jordan, „Cogent Business and Management“, 1, 8. https://doi.org/10.1080/23311975.2021.1883222

4. Hedija, V., Němec, D. (2021), Gender diversity in leadership and firm performance: Evidence from the czech republic, ,Journal of Business Economics and Management“, 1, 22, pp. 156180. https://doi.org/10.3846/jbem.2020.13680

5. https://www.bvdinfo.com/en-gb/our-products/catalyst/tp-catalyst\#secondaryMenuAnchor0 (access date: 12-05-2021)

6. https://datahelpdesk.worldbank.org/knowledgebase/articles/906519-world-bank-countryand-lending-groups (access date: 26-05-2021)

7. Nielsen, S., Huse, M. (2010), The contribution of women on boards of directors: Going beyond the surface, „Corporate Governance: An International Review“, 2, 18, pp.136-148.

8. Obrad, C., Gherheş, V. (2018), A human resources perspective on responsible corporate behavior. case study: The multinational companies in Western Romania, „Sustainability (Switzerland)“, 3, 10. https://doi.org/10.3390/su10030726

9. Patel, P., Meagher, K., El Achi, N., Ekzayez, A., Sullivan, R., Bowsher, G. (2020), Having more women humanitarian leaders will help transform the humanitarian system: Challenges and opportunities for women leaders in conflict and humanitarian health, „Conflict and Health“, 1, 14, pp. 1-15. https://doi.org/10.1186/s13031-020-00330-9

10. Potvin, D. A., Burdfield-Steel, E., Potvin, J. M., Heap, S. M. (2018), Diversity begets diversity: A global perspective on gender equality in scientific society leadership, „PLoS ONE“, 5, 13. https://doi.org/10.1371/journal.pone.0197280

11. Reddy, C. N., Adhikari, J., Chitranshi, J. (2017), Understanding and managing gender diversity challenges at leadership positions: A review, „Journal of Strategic Human Resource Management", 2, 6, pp. 40-44.

12. Sczesny, S., Bosak, J., Neff, D., Schyns, B. (2004), Gender stereotypes and the attribution of leadership traits: A cross-cultural comparison, „Sex roles“, 11/12, 51, pp. 631-645. https://doi.org/10.1007/s11199-004-0715-0 
13. Shaukat, A., Qiu, Y., Trojanowski, G. (2016), Board attributes, corporate social responsibility strategy, and corporate environmental and social performance, „Journal of Business Ethics“, 3, 135, pp. 569-585. https://doi.org/10.1007/s10551-014-2460-9

14. Tannen, D. (1991), You just don't understand: Women and men in conversation, Ballantine books, New York. 


\section{Annexes}

Annex A. Classification of companies within Europe Geo. Region company characteristic

\begin{tabular}{|l|c|}
\hline Region & Countries \\
\hline Nordics & Finland, Sweden \\
\hline Central & Germany, Poland, Switzerland \\
\hline Southern & Greece, Italy, Portugal, Spain \\
\hline Western & France, Ireland, Netherlands, United Kingdom \\
\hline Eastern & Croatia, Israel, Romania, Russian Federation, Turkey, Ukraine \\
\hline
\end{tabular}

Source: own research

\section{Annex B. Classification of companies within Ownership Capital Origin Country Economy company characteristic}

\begin{tabular}{|l|c|}
\hline Country Economy & Country \\
\hline High-income & $\begin{array}{c}\text { Australia, Austria, Bermuda, British Virgin Islands, Cayman Islands, } \\
\text { Croatia, Denmark, Finland, France, Germany, Greece, Ireland, Italy, } \\
\text { Liechtenstein, Luxembourg, Netherlands, Poland, Portugal, Romania, } \\
\text { Seychelles, Spain, Sweden, Switzerland, United Kingdom, United } \\
\text { States }\end{array}$ \\
\hline Middle-income & Brazil, China, Russian Federation, Turkey, Ukraine \\
\hline Low-income & Liberia \\
\hline
\end{tabular}

Source: own research based on World Bank country classification by GNI per capita

\section{Annex C. Classification of companies within Economy Sector company characteristic}

\begin{tabular}{|l|c|}
\hline Economy Sector & NACE Rev. 2 categorization of companies \\
\hline Primary & A - Agriculture, forestry and fishing; B - Mining and quarrying \\
\hline Secondary & $\begin{array}{r}\text { C - Manufacturing; D - Electricity, gas, steam and air } \\
\text { conditioning supply; F - Construction }\end{array}$ \\
Tertiary & $\begin{array}{c}\text { G - Wholesale and retail trade, repair of motor vehicles and } \\
\text { motorcycles; H - Transportation and storage; I - Accommodation } \\
\text { and food service activities; J - Information and communication; K - } \\
\text { Financial and insurance activities, L - Real estate activities; N - } \\
\text { Administrative and support service activities; O - Public } \\
\text { administration and defence, compulsory social security; Q - Human } \\
\text { health and social work activities; R - Arts, entertainment and } \\
\text { recreation; S - Other service activities }\end{array}$ \\
\hline Quaternary & M - Professional, scientific and technical activities \\
\hline
\end{tabular}

Source: own research based on TP Catalyst data 